\title{
INFLUENCE OF VERMICOMPOST AND NPK ON THE GROWTH AND PROTEIN CONTENT OF BORO RICE (Oryza sativa L.)
}

\author{
Nishi, K. N., S. Rahman, K. Nakamura ${ }^{1}$ and M. K. Rahman \\ Department of Soil, Water and Environment, University of Dhaka, Dhaka 1000, Bangladesh; ${ }^{1}$ Institute \\ for Agro-Environmental Sciences, NARO, Kannondai 3-1-3, Tsukuba, Ibaraki 305-0035, Japan
}

\begin{abstract}
Influence of vermicompost $(2.5,5,7.5$ and 10 ton/ha), Nitrogen (12, 24, 36, 48 and $60 \mathrm{~kg} / \mathrm{ha})$, phosphorus $(4,8,12,16$ and $20 \mathrm{~kg} / \mathrm{ha})$ and potassium $(10,20,30,40$ and $50 \mathrm{~kg} / \mathrm{ha})$ on the growth and protein contents of Boro rice (Oriza sativa L.) was examined. Highest height $(93.03 \mathrm{~cm})$, leaf number $(23 \mathrm{no} / \mathrm{plant})$, highest productive plants observed $(8.67 \mathrm{no} / \mathrm{pot})$, vegetative plants $(8.0 \mathrm{no} / \mathrm{pot})$, dry weight of panicle per plant $(9.45 \mathrm{~g})$, length of panicle $(22.37 \mathrm{~cm})$, number of grains per panicle (153.33),1000-grain weight $(21.56 \mathrm{~g})$ and the maximum dry weight (28.15 g/plant) were observed in $\mathrm{VC}_{10}$ ton/ha $+\mathrm{N}_{12} \mathrm{P}_{4} \mathrm{~K}_{10} \mathrm{~kg} / \mathrm{ha}$ treatments. Highest concentrations of protein content $(29.875 \%), \mathrm{P}(0.478 \%), \mathrm{K}(5.20 \%)$ and $\mathrm{S}(0.182 \%)$ were in $\mathrm{N}_{60} \mathrm{P}_{20} \mathrm{~K}_{50} \mathrm{~kg} / \mathrm{ha}$. Results showed that the overall best growth performance and yield were achieved in $\mathrm{VC}_{10}$ ton/ha $+\mathrm{N}_{12} \mathrm{P}_{4} \mathrm{~K}_{10}$ $\mathrm{kg} / \mathrm{ha}$ treatments.
\end{abstract}

Key words: Boro Rice; Vermicompost; Growth; Biomass production; NPK; Protein content.

\section{INTRODUCTION}

For Asian people living in lowland areas, the historical landscape is peaceful villages surrounded by rice fields with heavily bending golden ears of rice. Rice is cultivated in summer season and high yielding variety is more responsive to fertilizer and has greater potential in producing higher yields compared with the traditional varieties. Main sources of organic materials are plant residues (rice, weeds and algae) and rhizodeposition from rice and weed roots. They differ in quantity and quality and follow different pathways of input into soil, the former being added along with field management and the latter being by plant growth. The end products of organic materials are $\mathrm{CO}_{2}$ and $\mathrm{CH}_{4}$ in the rice field ecosystem, and they exit the system by water percolation to the subsoil layer and by flux to the atmosphere (Brune et al. 2000, Kimura 2000, Liesack et al. 2000). The kind and abundance of organic materials supplied to rice field ecosystems vary according to the kind and amount of fertilizers applied. Now a days a number of manures, viz. Majim, vermicompost, Shufola, GTS and poultry litter, are being used in Bangladesh. Vermicompost is peat-like material with low $\mathrm{C}: \mathrm{N}$ ratio, high porosity, aeration, drainage, water holding capacity, microbial activity and is the end product of non-thermophilic biodegradation of organic materials by combined action of earthworms and associated microbes. Organic manure is a good source of nutrients, especially $\mathrm{N}, \mathrm{P}$ and $\mathrm{S}$ and it's a good means of soil rejuvenation (Jeptoo et al. 2013). Organic manures like vermicomposts can be a good substitute for chemical fertilizers to overcome their adverse effects. Vermicompost are effective organic fertilizers and bio control agents (Simsek-Ersahin 2011, Joshi et al. 2013). Application of vermicompost singly or in combination with either other organic fertilizers or chemical fertilizers have been proved effective to enhance growth and yield of lilies, merigold, frenchbean, geranium, groundnut, sunflower, okra, cucumber, tomato, garlic, strawberry, spinach, maize, sorghum, lettuce and potato (Joshi et al. 2013). Use of organic manure could be an inevitable practice in the coming years for ensuring sustainable crop productivity without affecting soil fertility (Heikamp et al. 2011, Premsekhar and Rajashree 2009). Phosphorus and potassium play an important role in yield limiting towards disease and drought conditions (Fageria et al. 2003). Thus, this study was carried out to assess the influence of vermicompost and NPK on growth and yield of Boro rice. 


\section{MATERIAL AND METHODS}

Soil sample collection and some physical and chemical properties

Soil sample (0 to $15 \mathrm{~cm}$ depth) was collected from Dendabor, Savar upazila under Dhaka devision. The sample was air dried, ground and sieved by $2 \mathrm{~mm}$ sieve. The soil had a $\mathrm{pH} 6.72$, organic matter 0.56\% (Walkley and Black 1934), available N $21 \mathrm{mg} / \mathrm{kg}$ (Marr and Cresser 1983), available P $5.8 \mathrm{mg} / \mathrm{kg}$ (Murphy and Riley 1962), available K $31.1 \mathrm{mg} / \mathrm{kg}$,field capacity 25\% (Anderson and Ingram 1989), sand $8.12 \%$, silt 52.34\% and clay 39.54\%, textural class- silt loam (Bouyoucos 1962). The N, P and K concentration of vermicompost were $1.1,0.29$ and 0.82 per cents, respectively.

\section{Pot experiment}

A pot experiment was carried out in the net house of the Department of Soil, Water and Environment, University of Dhaka. Six kilograms of soil was taken per earthen pot $(25 \mathrm{~cm} \times 19 \mathrm{~cm})$. Vermicompost $(2.5,5,7.5$ and $10 \mathrm{ton} / \mathrm{ha})$, Nitrogen $(12,24,36,48$ and $60 \mathrm{~kg} / \mathrm{ha})$ as Urea, phosphorus $(4,8,12,16$ and $20 \mathrm{~kg} / \mathrm{ha})$ as TSP and potassium $(10,20,30,40$ and $50 \mathrm{~kg} / \mathrm{ha})$ as MP were applied. Pots were arranged in a completely randomized block design. Twenty days old seedlings of Boro Rice (Oryza sativa L.) collected from Goaria, Pabna district under Rajshahi division and four seedlings were transplanted per pot. The pots were watered about $100 \mathrm{ml}$ daily in the morning. Height, number of leaves and leaf area of the plants were measured at 120 days after harvest. The range of temperature, humidity and rainfall were $24^{\circ} \mathrm{C}$ to $33^{\circ} \mathrm{C}, 60 \%$ to $73 \%$ and 8 to $156 \mathrm{~mm}$, respectively during the experiment period (January to April) respectively. Height was measured from the soil level to the tip of the leaf, and leaf number was counted with the help of a tally counter at 40 days interval.

\section{Harvesting}

Four months old plants were harvested as root, shoot and grain root were washed with tap water and finally with distilled water, and wrapped with soft tissue paper. Immediately after the harvest and then air-dried in the room temperature and finally oven-dried at $65^{\circ} \mathrm{C}$ for 48 hours. The dry weight of the samples was recorded and the samples were ground with a mechanical grinder and stored in the paper bags for further chemical analysis. For nitrogen, $0.2 \mathrm{~g}$ of yield sample was digested in a Kjeldahl digestion flask (Jackson 1962) and for P and K, 0.5g yield was digested (Shelton and Harper 1941). The phosphorous of the digest was determined by the vanadomolybdophosphoric yellow colour method at $430 \mathrm{~nm}$ using spectrophotometer (model DR 5000). Potassium in the digest was determined by using JENWAY flame photometer (model PFP 7). Protein contents of the yield samples were estimated by multiplying the total Nitrogen by 6.25 (AOAC 1990). Results were statistically analyzed using Microsoft Excel 2007 and Software Minitab 19.

\section{RESULTS AND DISCUSSION}

Growth of plant was measured in terms of plant height and leaf number (Table 1), yield attributes (Table 2), biomass production as root and shoot, and concentrations of NPKS and protein content of rice (Table 3). Height and leaf number increased with the dose of treatments (Table 1) and varied significantly $(\mathrm{p}<0.05)$. However, the highest height $(93.03 \mathrm{~cm})$ was observed in the $\mathrm{VC}_{10}$ ton/ha + $\mathrm{N}_{12} \mathrm{P}_{4} \mathrm{~K}_{10} \mathrm{~kg} / \mathrm{ha}$ treatments. The lowest height was observed in Control. The highest value of leaf number was 23 recorded in $\mathrm{VC}_{10}$ ton/ha $+\mathrm{N}_{12} \mathrm{P}_{4} \mathrm{~K}_{10} \mathrm{~kg} / \mathrm{ha}$ treatments and lowest value was observed in $\mathrm{VC}_{2.5}$ ton/ha treatment. Vermicompost accelerates plant growth directly by supplying nutrients and indirectly by enhancing the communities of plant friendly microbes by suppressing soil borne diseases (Canellas et al. 2002). 
Table 1. Influence of vermicompost and NPK on the height $(\mathrm{cm})$ and leaf number of Boro rice (Oryza sativa $\mathrm{L}$.).

\begin{tabular}{|c|c|c|c|c|c|c|}
\hline \multirow[t]{2}{*}{ Treatments } & \multicolumn{3}{|c|}{ Plant Height } & \multicolumn{3}{|c|}{ Leaf Number } \\
\hline & 40 & 80 & 120 & 40 & 80 & 120 \\
\hline Control (- VC \& - NPK) & $20.93^{f}$ & $62.83^{\mathrm{c}}$ & $79.03^{f}$ & $4.67^{\mathrm{a}}$ & $10.33^{\mathrm{abcd}}$ & $13.33^{\mathrm{ef}}$ \\
\hline $\mathrm{VC}_{2.5}$ ton/ha & $28.00^{\mathrm{de}}$ & $60.13^{\mathrm{d}}$ & $80.87^{\mathrm{ef}}$ & $6.00^{\mathrm{a}}$ & $7.00^{\mathrm{d}}$ & $10.67^{\mathrm{f}}$ \\
\hline $\mathrm{VC}_{5}$ ton/ha & $30.00^{\mathrm{abcd}}$ & $65.10^{\mathrm{b}}$ & $83.13^{\text {cdef }}$ & $6.00^{\mathrm{a}}$ & $9.67^{\mathrm{bcd}}$ & $16.67^{\text {cde }}$ \\
\hline $\mathrm{VC}_{7.5}$ ton/ha & $28.73^{\text {cde }}$ & $65.13^{\mathrm{b}}$ & $84.63^{\text {bcde }}$ & $6.67^{\mathrm{a}}$ & $11.00^{\mathrm{abc}}$ & $19.67^{\mathrm{abc}}$ \\
\hline $\mathrm{VC}_{10}$ ton/ha & $29.13^{\text {bcde }}$ & $64.30^{\mathrm{bc}}$ & $89.07^{\mathrm{ab}}$ & $6.33^{\mathrm{a}}$ & $12.00^{\mathrm{abc}}$ & $19.00^{\mathrm{bcd}}$ \\
\hline $\mathrm{N}_{60} \mathrm{P}_{20} \mathrm{~K}_{50} \mathrm{~kg} / \mathrm{h}(100 \% \mathrm{NPK})$ & $31.80^{\mathrm{abc}}$ & $67.23^{\mathrm{a}}$ & $88.13^{\mathrm{abc}}$ & $6.33^{\mathrm{a}}$ & $13.67^{\mathrm{a}}$ & $22.67^{\mathrm{a}}$ \\
\hline $\mathrm{VC}_{2.5}$ ton/ha $+\mathrm{N}_{48} \mathrm{P}_{16} \mathrm{~K}_{40} \mathrm{~kg} / \mathrm{ha}(80 \% \mathrm{NPK})$ & $26.47^{\mathrm{e}}$ & $56.50^{\mathrm{e}}$ & $79.17^{\mathrm{f}}$ & $5.33^{\mathrm{a}}$ & $9.00^{\mathrm{cd}}$ & $16.00^{\text {de }}$ \\
\hline $\mathrm{VC}_{5}$ ton $/ \mathrm{ha}+\mathrm{N}_{36} \mathrm{P}_{12} \mathrm{~K}_{30} \mathrm{~kg} / \mathrm{ha}(60 \% \mathrm{NPK})$ & $32.40^{\mathrm{a}}$ & $59.87^{\mathrm{d}}$ & $81.07^{\mathrm{def}}$ & $6.67^{\mathrm{a}}$ & $12.67^{\mathrm{abc}}$ & $22.67^{\mathrm{a}}$ \\
\hline $\mathrm{VC}_{7.5}$ ton $/ \mathrm{ha}+\mathrm{N}_{24} \mathrm{P}_{8} \mathrm{~K}_{20} \mathrm{~kg} / \mathrm{ha}(40 \% \mathrm{NPK})$ & $29.97^{\mathrm{abcd}}$ & $61.00^{\mathrm{d}}$ & $85.90^{\text {bcd }}$ & $6.67^{\mathrm{a}}$ & $13.00^{\mathrm{ab}}$ & $21.00^{\mathrm{ab}}$ \\
\hline $\mathrm{VC}_{10}$ ton/ha $+\mathrm{N}_{12} \mathrm{P}_{4} \mathrm{~K}_{10} \mathrm{~kg} / \mathrm{ha}(20 \% \mathrm{NPK})$ & $32.00^{\mathrm{ab}}$ & $64.47^{\mathrm{bc}}$ & $93.03^{\mathrm{a}}$ & $6.67^{\mathrm{a}}$ & $13.67^{\mathrm{a}}$ & $23.00^{\mathrm{a}}$ \\
\hline
\end{tabular}

Results presented in Table 2 shows that number of productive plants per pot increased due to all treatments and maximum increase was found in $\mathrm{VC}_{10}$ ton/ha $+\mathrm{N}_{12} \mathrm{P}_{4} \mathrm{~K}_{10} \mathrm{~kg} / \mathrm{ha}$ treatments and the value was 8.67. The highest dry weight of panicle per plant was $9.45 \mathrm{~g}$ found in $\mathrm{VC}_{10}$ ton/ha $+\mathrm{N}_{12} \mathrm{P}_{4} \mathrm{~K}_{10} \mathrm{~kg} / \mathrm{ha}$ treatments and that of the lowest was $0.66 \mathrm{~g}$ found in Control.

Significantly highest length of panicle was $22.37 \mathrm{~cm}$ was found $\mathrm{VC}_{10}$ ton/ha $+\mathrm{N}_{12} \mathrm{P}_{4} \mathrm{~K}_{10} \mathrm{~kg} / \mathrm{ha}$ treatments and that of the lowest value was $17.1 \mathrm{~cm}$ found in Control. Number of grains per panicle rice responded positively following all treatments. The highest number of grains per panicle,153.33 was found in $\mathrm{VC}_{10}$ ton/ha $+\mathrm{N}_{12} \mathrm{P}_{4} \mathrm{~K}_{10} \mathrm{~kg} / \mathrm{ha}$ treatments and the lowest value, 70.33 was found in Control.

Table 2. Influence of vermicompost and NPK on the yield attributes and yield of Boro rice ( Oryza sativa L.).

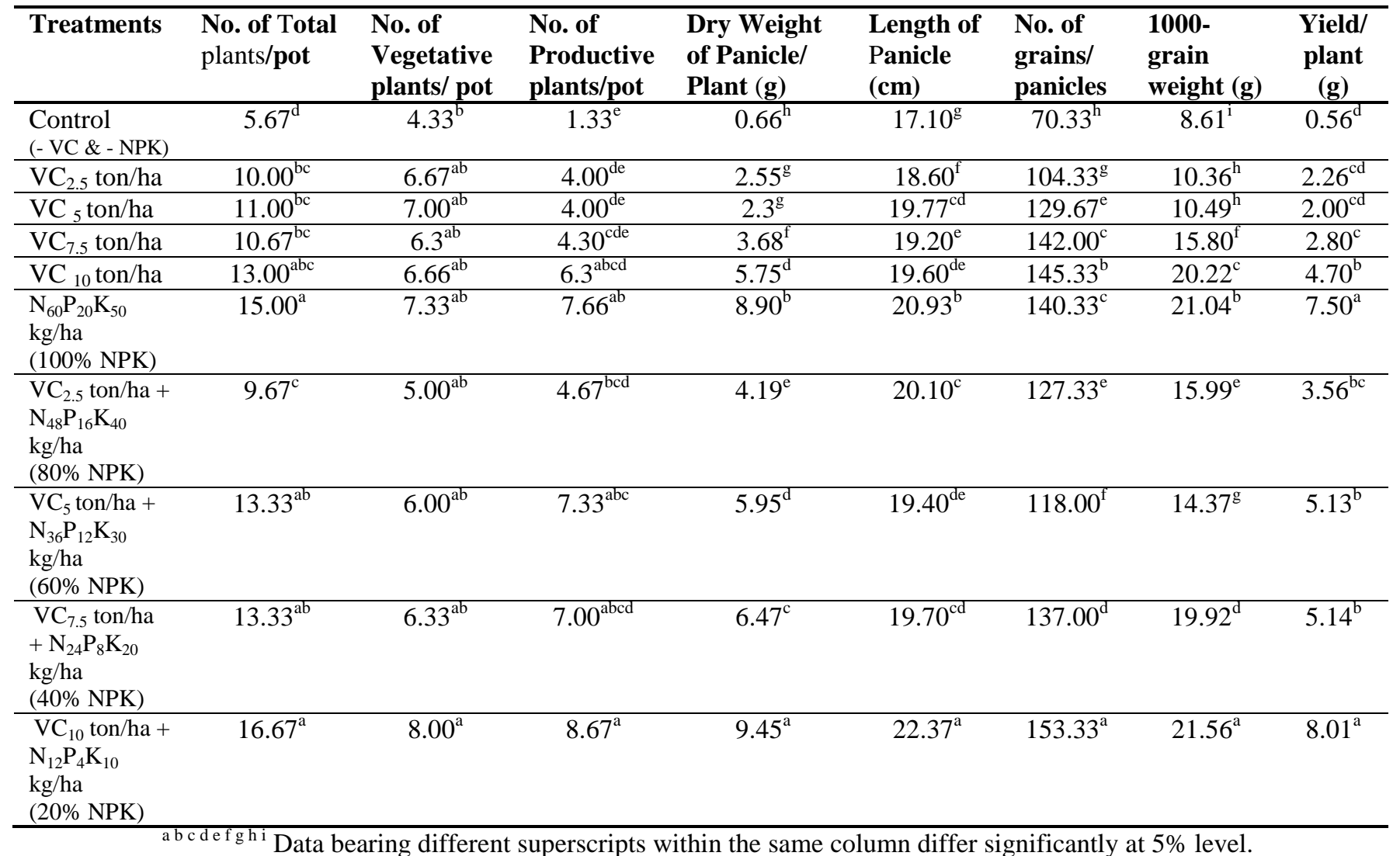


Weight of 1000-grain increased due to treatments in rice. The maximum 1000-grain weight was found in $\mathrm{VC}_{10}$ ton/ha $+\mathrm{N}_{12} \mathrm{P}_{4} \mathrm{~K}_{10} \mathrm{~kg} / \mathrm{ha}$ treatments that is $21.56 \mathrm{~g}$ which was significantly higher than Control. Maximum yield of Boro rice per plant $(8.01 \mathrm{~g})$ was obtained from $\mathrm{VC}_{10}$ ton/ha $+\mathrm{N}_{12} \mathrm{P}_{4} \mathrm{~K}_{10}$ $\mathrm{kg} / \mathrm{ha}$ treatments fertilization (NPK) and vermicompost, yield was increased primarily due to an increase in recovery and agronomic efficiency.

\section{Dry matter yields}

The yields of dry weights of root and shoot were shown in Table 3. The highest yields were measured in $\mathrm{VC}_{10}$ ton/ha $+\mathrm{N}_{12} \mathrm{P}_{4} \mathrm{~K}_{10} \mathrm{~kg} / \mathrm{ha}$ treatments. The maximum dry weight was $28.15 \mathrm{~g} / \mathrm{plant}$, found in $\mathrm{VC}_{10}$ ton/ha $+\mathrm{N}_{12} \mathrm{P}_{4} \mathrm{~K}_{10} \mathrm{~kg} / \mathrm{ha}$ treatments.

Concentration of $\mathrm{P}, \mathrm{K}, \mathrm{S}$ and protein content were measured through different treatments. The highest protein content $\left(29.87 \%\right.$ ) was found in $\mathrm{N}_{60} \mathrm{P}_{20} \mathrm{~K}_{50} \mathrm{~kg} / \mathrm{ha}$ treatments. Plants observed more nitrogen and converted into protein than other treatments. The lowest protein content $(7.06 \%)$ was found in Control. The highest $\mathrm{P}$ concentration $(0.478 \%)$ found in $\mathrm{N}_{60} \mathrm{P}_{20} \mathrm{~K}_{50}$ treatments. Both the highest concentration of $\mathrm{K}(5.2 \%)$ and $\mathrm{S}(0.182 \%)$ were found in $\mathrm{N}_{60} \mathrm{P}_{20} \mathrm{~K}_{50} \mathrm{~kg} / \mathrm{ha}$ treatments. This significant crop yield might be due to the improved physical environment of the soil as affected by vermicompost (Aruna and Shaik 2005).

Table 3. Influence of vermicompost and NPK on dry weight and the concentration (\%) of PKS and protein content in the yield of Boro rice (Oryza sativa $\mathrm{L}$.).

\begin{tabular}{|c|c|c|c|c|c|c|c|}
\hline Treatments & $\begin{array}{l}\text { Dry weight } \\
\text { of Root (g) }\end{array}$ & $\begin{array}{l}\text { Dry weight } \\
\text { of Shoot }(\mathrm{g})\end{array}$ & $\begin{array}{c}\text { Total } \\
(\mathrm{g})\end{array}$ & $\begin{array}{c}\begin{array}{c}\text { Protein } \\
\text { content }(\%)\end{array} \\
\end{array}$ & $\mathbf{P}(\%)$ & $\mathbf{K}(\%)$ & $\mathbf{S}(\%)$ \\
\hline Control (- VC \& - NPK) & $4.30^{\mathrm{j}}$ & $9.77^{\mathrm{de}}$ & $14.07^{\mathrm{e}}$ & $7.06^{\mathrm{e}}$ & $0.248^{\mathrm{h}}$ & $3.20^{\mathrm{e}}$ & $0.074^{\mathrm{c}}$ \\
\hline $\mathrm{VC}_{2.5}$ ton/ha & $4.78^{i}$ & $7.01^{\mathrm{g}}$ & $11.79^{\mathrm{f}}$ & $8.56^{\mathrm{d}}$ & $0.276^{\mathrm{g}}$ & $3.70^{\mathrm{d}}$ & $0.077^{\text {be }}$ \\
\hline $\mathrm{VC}_{5}$ ton/ha & $7.04^{\mathrm{f}}$ & $10.29^{\mathrm{cd}}$ & $17.33^{\mathrm{d}}$ & $8.94^{\mathrm{d}}$ & $0.279^{\mathrm{fg}}$ & $3.70^{\mathrm{d}}$ & $0.085^{\mathrm{bc}}$ \\
\hline $\mathrm{VC}_{7.5}$ ton/ha & $8.36^{\mathrm{c}}$ & $11.39^{\mathrm{bc}}$ & $19.76^{\mathrm{c}}$ & $12.62^{\mathrm{c}}$ & $0.296^{\mathrm{f}}$ & $4.30 \mathrm{c}$ & $0.091^{\mathrm{bc}}$ \\
\hline $\mathrm{VC}_{10}$ ton/ha & $8.71^{\mathrm{b}}$ & $14.47^{\mathrm{a}}$ & $23.19^{b}$ & $20.19^{b}$ & $0.389^{\mathrm{e}}$ & $4.80^{\mathrm{ab}}$ & $0.093^{\mathrm{b}}$ \\
\hline $\mathrm{N}_{60} \mathrm{P}_{20} \mathrm{~K}_{50} \mathrm{~kg} / \mathrm{ha}(100 \% \mathrm{NPK})$ & $8.13^{\mathrm{d}}$ & $11.54^{\mathrm{b}}$ & $19.67^{\mathrm{c}}$ & $29.87^{\mathrm{a}}$ & $0.478^{\mathrm{a}}$ & $5.20^{\mathrm{a}}$ & $0.182^{\mathrm{a}}$ \\
\hline $\begin{array}{l}\mathrm{VC}_{2.5} \text { ton/ha }+\mathrm{N}_{48} \mathrm{P}_{16} \mathrm{~K}_{40} \mathrm{~kg} / \mathrm{ha}(80 \% \\
\mathrm{NPK})\end{array}$ & $5.69^{\mathrm{h}}$ & $8.50^{\mathrm{f}}$ & $14.18^{\mathrm{e}}$ & $28.19^{\mathrm{a}}$ & $0.436^{\text {cd }}$ & $5.06^{\mathrm{ab}}$ & $0.179^{\mathrm{a}}$ \\
\hline $\begin{array}{l}\mathrm{VC}_{5} \text { ton } / \mathrm{ha}+\mathrm{N}_{36} \mathrm{P}_{12} \mathrm{~K}_{30} \mathrm{~kg} / \mathrm{ha} \\
(60 \% \mathrm{NPK})\end{array}$ & $5.95^{\mathrm{g}}$ & $9.05^{\mathrm{ef}}$ & $15.00^{\mathrm{e}}$ & $29.37^{\mathrm{a}}$ & $0.431^{\mathrm{d}}$ & $4.60^{\mathrm{bc}}$ & $0.178^{\mathrm{a}}$ \\
\hline $\begin{array}{l}\mathrm{VC}_{7.5} \text { ton/ha }+\mathrm{N}_{24} \mathrm{P}_{8} \mathrm{~K}_{20} \mathrm{~kg} / \mathrm{ha} \\
(40 \% \mathrm{NPK})\end{array}$ & $7.93^{\mathrm{e}}$ & $10.33^{\text {cd }}$ & $18.26^{\text {cd }}$ & $29.19^{\mathrm{a}}$ & $0.450^{\mathrm{bc}}$ & $5.03^{\mathrm{ab}}$ & $0.18^{\mathrm{a}}$ \\
\hline $\begin{array}{l}\mathrm{VC}_{10} \text { ton } / \mathrm{ha}+\mathrm{N}_{12} \mathrm{P}_{4} \mathrm{~K}_{10} \mathrm{~kg} / \mathrm{ha} \\
(20 \% \mathrm{NPK})\end{array}$ & $13.48^{\mathrm{a}}$ & $14.67^{\mathrm{a}}$ & $28.15^{\mathrm{a}}$ & $29.12^{\mathrm{a}}$ & $0.457^{b}$ & $4.97^{\mathrm{ab}}$ & $0.178^{\mathrm{a}}$ \\
\hline
\end{tabular}

The overall results of this experiment indicated that vermicompost and NPK shared better effects on growth and yield attribute significantly of Boro rice. Better yield was achieved in $\mathrm{VC}_{10}$ ton/ha + $\mathrm{N}_{12} \mathrm{P}_{4} \mathrm{~K}_{10} \mathrm{~kg} / \mathrm{ha}$ treatments and nutrient uptake was found in $\mathrm{N}_{60} \mathrm{P}_{20} \mathrm{~K}_{50} \mathrm{~kg} /$ ha treatments.

\section{REFERENCES}

Anderson, J. M. and J. S. I. Ingram. 1989. Soil Physical Analysis: Field Capacity. In: J. M. Anderson and J. S. I. Ingram (eds.). Tropical Soil Biology and Fertility: A Handbook of Methods. CAB International, Oxon OX10 8DE, Wallingford, UK., pp. 50-51. 
Aruna, E. and M. Shaik. 2005. Influence of conjuctive use of organic and inorganic source of nutrients in rice (Oryza sativa) on crop growth, yield components, yield and soil fertility in rice sunflower (Helianthus annuus) sequence. Indian J. Agron. 50(4): 265-268.

Association of Official Analytical Chemists (AOAC). 1990. Official Methods of Analysis, 15th ed. AOAC, Washington D.C. USA. 556 pp.

Bouyoucos, G. T. 1962. Hydrometer method improved for making particle size analysis of soils. Agron. J. 54: 461-465.

Brune, A., P. Frenzel and H. Cypionka. 2000. Life at the oxic-anoxic interface: microbial activities and adaptation. FEMS Microbiol. Rev. 24: 691-710.

Canellas, L. P., F. L. Olivares., A. L. Okorokova-Façanha and A. R. Facanha. 2002. Humic acids isolated from earthworm compost enhance root elongation, lateral root emergence, and plasma membrane $\mathrm{H}^{+}$-ATPase activity in maize roots. Plant Physiol. 130: 1951-1957.

Fageria, N. K., A. B. Slaton and V. C. Baligar. 2003. Nutrient Management for Improving Lowland Rice Productivity and Sustainability. Advances in Agron. 80: 63-152.

Heitkamp, F., J. Raupp and B. Ludwig. 2011. Soil organic matter pools and crop yields as affected by the rate of farmyard manure and use of biodynamic preparations in a sandy soil. Organic Agric. 11: 111-124.

Jackson, M. L. 1962. Soil Chemical Analysis. Constable and Co. Ltd., London, UK. 521 pp.

Jeptoo, A., J. N. Aguyoh and M. Saidi. 2013. Improving Carrot Yield and Quality through the Use of Bio-Slurry Manure. Sustainable Agric. Res. 2(1): 164-172.

Joshi, R., A. P. Vig and J. Singh. 2013.Vermicompost as soil supplement to enhance growth, yield and quality of Triticim astivum L.: a field study. Int. J. Recycling Organic Waste Agric. 2: 16.

Kimura, M. 2000. Anaerobic microbiology in waterlogged rice fields. In: J. M. Bollag and G. Stotzky (eds.). Soil Biochemistry. Vol. 10. Marcell Dekker, New York, USA., pp. 35-138.

Liesack, W., S. Schnell, N. P. Revsbech. 2000. Microbiology of flooded rice paddies. FEMS Microbiol. Rev. 24: 625-645.

Marr, I. L. and M. S. Cresser. 1983. The lithosphere. In: S. Mitra, P. Patnaik and B. B. Kebbekus (eds.). Environmental Chemical Analysis. Blackie and Son, UK., pp. 155-182.

Murphy, J. and J. P. Riley. 1962. A modified single solution method for the determination of phosphate in natural waters. Anal. Chim. Acta. 27: 31-36

Premsekhar, M. and V. Rajashree. 2009. Influence Organic Manures on Growth, Yield and Quality of Okra. . Am-Eurasian J. Sustainable Agric. 3(1): 6-8.

Shelton, W. R. and H. J. Harper. 1941. A rapid method for the determination of total phosphorus in soil and plant material. Iowa State Coll. J. Sci. 15: 403-413.

Simsek-Ersahin, Y. 2011. The use of vermicompost products to control plant diseases and past. In: A. Karaca (ed.). Biology of Earthwarms (Soil Biology). Sprinqer-Verlaq, Heidelberg, Berlin, Germany., pp. 191-213.

Walkley, A. and I. A. Black.1934. An examination of the Degtjareff method for determining soil organic matter and a proposed modification of the chromic acid titration method. Soil Sci. 37: 29-38.

Watson, C. A., D. Atkinson, P. Gosling, L. R. Jackson and F. W. Rayns. 2002. Managing soil fertility in organic farming systems. Soil Use Manage. 18: 239-247. 
